\title{
HETEROCYCLES 45. SYNTHESIS, CHARACTERIZATION AND BIOLOGICAL EVALUATION OF 3-INDOLYL-1-PYRIDYL-2- PROPENONES AS ANTICANCER AGENTS
}

\author{
JUSTIN KAMGA $^{1,2}$, DENISA LEONTE ${ }^{2}$, PANTALEON AMBASSA ${ }^{1}$, ARMELLE T. MBAVENG $^{3,5}$, \\ GHISLAIN W. FOTSO ${ }^{1}$, FANA-MARIA COMAN ${ }^{2}$, BONAVENTURE T. NGADJUI ${ }^{1,4}$, VICTOR \\ KUETE $^{3,5}$, VALENTIN ZAHARIA ${ }^{2 *}$, BATHELEMY NGAMENI ${ }^{4}$ \\ ${ }^{1}$ Department of Organic Chemistry, University of Yaounde I, P.O. Box 812, Yaounde, Cameroon \\ ${ }^{2}$ Department of Organic Chemistry, "Iuliu Haţieganu" University of Medicine and Pharmacy, 41 Victor Babeş Street, 400012, \\ Cluj-Napoca, Romania \\ ${ }^{3}$ Department of Biochemistry, University of Dschang, P.O. Box 67, Dschang, Cameroon \\ ${ }^{4}$ Department of Pharmacognosy and Pharmaceutical Chemistry, University of Yaounde I, P.O. Box 1364, Yaounde, Cameroon \\ ${ }^{5}$ Institute of Pharmacy and Biochemistry, Therapeutical Life Sciences, 55128, Mainz, Germany
}

*corresponding author: vzaharia@umfcluj.ro

Manuscript received: March 2020

\begin{abstract}
A series of seven 3-indolyl-1-pyridyl-2-propenones were synthesized via Claisen-Schmidt condensation with $68.8-91.8 \%$ yields. All the synthesized compounds were purified and characterized by melting points, IR, ${ }^{1} \mathrm{H} N \mathrm{NR},{ }^{13} \mathrm{C}$ NMR and HRMS. The cytotoxicity of the synthesized 3-indolyl-1-pyridyl-2-propenones 1-7 and doxorubicin, used as positive control, was determined in a panel of nine human cancer cell lines including both sensitive and drug-resistant phenotypes, as well as in normal AML12 hepatocytes. Compounds $\mathbf{3 , 4}$ and $\mathbf{7}$ displayed half maximal inhibitory concentration $\left(\mathrm{IC}_{50}\right.$ ) values below $100 \mu \mathrm{M}$ in all tested cancer cell lines meanwhile, other compounds displayed selective activities.
\end{abstract}

\section{Rezumat}

O serie de 3-indolil-1-piridil-2-propenone 1-7 au fost sintetizate prin reacția de condensare Claisen-Schmidt cu randamente cuprinse între 68,8 și 91,8\%. Toți compușii sintetizați au fost purificați și caracterizați prin punctele de topire și prin metode spectrale: IR, ${ }^{1} \mathrm{H}$ RMN, ${ }^{13} \mathrm{C}$ RMN și HRMS. Citotoxicitatea compușilor sintetizați a fost evaluată pe nouă linii celulare canceroase, atât pe fenotipuri sensibile, cât și pe fenotipuri rezistente la medicația actuală, utilizând doxorubicina ca substanță antiproliferativă de referință. Citotoxicitatea compușilor a fost testată și pe hepatocite normale. Compușii 3, 4 și 7 au prezentat valori ale concentrațiilor minime inhibitorii ( $\left.\mathrm{CI}_{50}\right)$ mai mici de $100 \mu \mathrm{M}$ pe toate liniile celulare testate, în timp ce alți compuși au prezentat activități selective.

Keywords: chalcones, anticancer agents, cytotoxicity, selectivity

\section{Introduction}

The development of new anticancer agents is currently a worldwide health issue, since cancer has become one of the leading causes of mortality in the entire world $[25,28]$. One of the major problems that occur in anticancer drug therapy is the lack of selectivity of drugs that lead to cancer chemotherapy failure. In addition, many cancer cell lines have become resistant to the available drugs [28]. It is therefore important to design new molecules which have different structures from the ones currently used in therapy, which could act selectively on cancer cells.

Several researches showed that natural products are promising antineoplastic agents, many of them presenting low toxicity and good selectivity $[6,8,9]$. An increasing number of natural products are currently promising anticancer drug candidates or key structures for the design of new synthetic/semisynthetic analogues with enhanced activities.

Chalcones are organic compounds with natural origins possessing the general structure 1,3-diaryl-2-propen1 -one. They are intensively studied in the medicinal field, because of their remarkable biological potential. In plants, chalcones have multiple roles, being involved in natural defence mechanisms and in different biosynthetic pathways, since they are the biosynthetic precursors of flavonoids and isoflavonoids [15, 2527, 31].

Starting from the general structure of natural chalcones, new synthetic analogues were obtained and evaluated for their biological potential. Polyhydroxylated and indole derived chalcones were shown to have antiinflammatory activity [20, 30]. Some chalcone analogues containing heterocyclic moieties such as pyridine or furane possess inhibitory activity against Mycobacterium 
tuberculosis [14]. Several multi-substituted chalcones were found to have antifungal activities [12]. Chalcones with chlorine and fluorine atoms on ring A and electrondonating groups on ring $\mathrm{B}$ exhibited strong antimalarial activities against both chloroquine-resistant strain and chloroquine-sensitive strain. Chalcone derivatives containing fluorine, bromine or nitro groups have been reported to possess good anti-leishmanial activity [2, $13,17]$. Besides these activities, the anticancer potential of various heterocyclic chalcone analogues is largely reported [1, 5, 11, 24]. Structure-activity relationships were established based on the biological evaluation of synthetic chalcones containing various substituents grafted on the two aromatic rings. The antioxidant activity of chalcones and their flavonoidic derivatives is due to different mechanisms such as free radical scavenging, hydrogen donation, singlet oxygen quenching and metal ion chelation [19].

Synthetic analogues of chalcones possessing different heterocyclic rings such as thiazole, pyrazole and indole proved to be effective anticancer agents, even on cancer resistant cell lines [5, 25]. Indole based chalcones showed interesting cytotoxic activity and selectivity, but several studies are necessary to be performed in order to establish their mechanism of action $[4,11]$. Being aware of the biological potential of indole, pyridine and chalcone moieties, we oriented our research to the synthesis of new 3-indolyl-1-pyridyl-2-propenones with various structural modifications, in order to evaluate their anticancer potential.

\section{Materials and Methods}

All chemicals and reagents used in this study were purchased from Sigma-Aldrich, Fluka and Merck Chemical Co. The progress of the reactions was monitored by thin layer chromatography (TLC), which was performed on aluminium sheet pre-coated with silica gel, kieselgel $60 \mathrm{~F}_{254}$ (Merck) and the spots were visualized under a UV lamp at $254 \mathrm{~nm}$. Preparative chromatographic purifications were performed using Merck Kieselgel 60 Å column chromatography.

Melting points of synthesized compounds were determined in open capillary tubes, with an Electrothermal IA 9000 digital apparatus and are uncorrected. The infrared (IR) spectra were recorded on Shimadzu Fourier transform infrared (FTIR) spectrophotometer. ${ }^{1} \mathrm{H}$ and ${ }^{13} \mathrm{C}$ NMR spectra were recorded with Bruker WM-400 in dimethylsulphoxide (DMSO-d6) at 400 and $100 \mathrm{MHz}$, respectively, using tetramethylsilane as the internal standard. Chemical shifts were recorded as $\delta$ (ppm). Coupling constant $(\mathrm{J})$ are referred in Hertz $(\mathrm{Hz})$. The following abbreviations for peak patterns were used: s - singlet, d - doublet, dd - double doublet, $\mathrm{t}$ - triplet, $\mathrm{q}$ - quartet, brs - broad signal. Mass spectra were obtained using a Bruker FTMS 4.7T BioAPEX II. Spectra facilities were carried out by analytical instruments facility division of the
Faculty of Science, University of Lorraine, France. Compounds 3b-e was obtained by alkylation of indol-3-carbaldehyde 3a with different alkylating agents and compounds 1-7 were synthesized by ClaisenSchmidt condensation, according to the previous literature [29].

General procedure for the synthesis of compounds 3b-e and 1-7

Synthesis of indol-3-carbaldehyde derivatives ( $3 \boldsymbol{b}-\boldsymbol{e})$ A mixture of indole-3-carbaldehyde $3 \mathbf{a}(10 \mathrm{mmol})$, the appropriate alkylating reagent $\mathbf{2 b}-\mathbf{e}(10.85 \mathrm{mmol}$ of methyl iodide/ethyl iodide/allyl bromide/benzyl chloride respectively), anhydrous $\mathrm{K}_{2} \mathrm{CO}_{3}(1.4 \mathrm{~g})$ and $\mathrm{N}, \mathrm{N}$-dimethylformamide $(10 \mathrm{~mL})$ was stirred vigorously at room temperature for 1 hour and then refluxed for 16 - $24 \mathrm{~h}$. After completion of the reaction as monitored by TLC (eluent petroleum ether:ethyl acetate $4: 1 \mathrm{v} / \mathrm{v}$ ), the cooled reaction mixture was poured into water $(40 \mathrm{~mL})$ and the precipitated solid was collected by filtration and air dried. After the purification with the appropriate eluent mixture petroleum ether:ethyl acetate $4: 1 \mathrm{v} / \mathrm{v}$, the pure compounds 3b-e were obtained (Figure 1).

Synthesis of 3-indolyl-1-pyridyl-2-propenones (1-7) A mixture of indol-3-carbaldehyde derivative 3a-e $(1.06 \mathrm{mmol})$ and the appropriate acetylpyridine (1.58 mmol) in anhydrous methanol $(15 \mathrm{~mL})$ was refluxed in the presence of piperidine $(1.58 \mathrm{mmol})$ for $20-26 \mathrm{~h}$. The reaction course was monitored by TLC using as eluent a mixture of dichloromethane:acetone 9:1 v/v. The formed precipitate was filtered, washed with icecold methanol and air dried for $24 \mathrm{~h}$ to obtain a pure bright orange or yellow powder $1,4,5,6$, 7, except for compounds $\mathbf{2}$ and $\mathbf{3}$ which have been purified by column chromatography on silica gel (Merck, 230 - 400 mesh) using as eluent a mixture of dichloromethane: acetone $9: 1 \mathrm{v} / \mathrm{v}$ to afford the pure products as orange powder.

E-3-(1H-Indol-3-yl)-1-(pyridin-4-yl)prop-2-en-1-one (1)

Yield $72.03 \%$, bright orange powder, mp $273-274^{\circ} \mathrm{C}$; IR $\left(\mathrm{KBr}, \mathrm{cm}^{-1}\right): v_{\max } 3090(\mathrm{NH}), 1648(\mathrm{C}=\mathrm{O}), 1604$ $(\mathrm{C}=\mathrm{N}), 1563(\mathrm{C}=\mathrm{N}), 1544,1542 ;{ }^{1} \mathrm{H} \mathrm{NMR}(400 \mathrm{MHz}$, dimethyl sulfoxide DMSO-d 6 ): $\delta 7.24(\mathrm{~m}, 1 \mathrm{H}, \mathrm{Ar}-\mathrm{H})$; $7.27(\mathrm{~m}, 1 \mathrm{H}, \mathrm{m}, \mathrm{Ar}-\mathrm{H}) ; 7.52(\mathrm{~d}, 1 \mathrm{H}, J=1.2$ and $6.8 \mathrm{~Hz}$, $\mathrm{Ar}-\mathrm{H}) ; 7.58\left(\mathrm{~d}, 1 \mathrm{H}, J=15.6 \mathrm{~Hz}, \mathrm{H}_{\alpha}\right) ; 7.97$ (d, 2H, $J=$ $6.0 \mathrm{~Hz}, \mathrm{Ar}-\mathrm{H}) ; 8.11(\mathrm{~d}, 1 \mathrm{H}, J=1.2$ and $6.8 \mathrm{~Hz}, \mathrm{Ar}-$ $\mathrm{H}) ; 8.18\left(\mathrm{~d}, 1 \mathrm{H}, J=15.2 \mathrm{~Hz}, \mathrm{H}_{\beta}\right) ; 8.83(\mathrm{~d}, 2 \mathrm{H} J=$ $6.4 \mathrm{~Hz}, \mathrm{Ar}-\mathrm{H}) ; 12.03(1 \mathrm{H}, \mathrm{s}, \mathrm{NH}) ;{ }^{13} \mathrm{C} \mathrm{NMR}(100$ MHz, DMSO-d6): $\delta 112.5 ; 112.8 ; 114.7 ; 120.5 ; 121.3$; $121.4 ; 122.9 ; 125.0 ; 134.4 ; 137.6 ; 140.8 ; 144.7 ; 150.6$; 188.4; ESIMS (Bruker FTMS 4.7T BioAPEX II, $\mathrm{CHCl} 3 / \mathrm{ACN}) \mathrm{m} / \mathrm{z}=249.1019(\mathrm{M}+\mathrm{H})^{+}$, calculated for $\mathrm{C}_{16} \mathrm{H}_{13} \mathrm{~N}_{2} \mathrm{O}^{+}$: 249.09 .

E-3-(1-Methylindol-3-yl)-1-(pyridin-4-yl)prop-2-en-1one (2)

Yield $90.57 \%$, orange powder, mp $152-154^{\circ} \mathrm{C}$; IR $\left(\mathrm{KBr}, \mathrm{cm}^{-1}\right): v_{\max } 1644(\mathrm{C}=\mathrm{O}), 1592(\mathrm{C}=\mathrm{N}), 1561(\mathrm{C}=\mathrm{C})$, 
FARMACIA, 2020, Vol. 68, 4

1543; ${ }^{1} \mathrm{H}$ NMR (400 MHz, DMSO-d 6 ): $\delta 3.875$ (s, $\left.3 \mathrm{H}, \mathrm{NCH}_{3}\right), 7.321(\mathrm{~m}, 1 \mathrm{H}, \mathrm{Ar}-\mathrm{H}), 7.344(\mathrm{~m}, 1 \mathrm{H}, \mathrm{Ar}-\mathrm{H})$, $7.574\left(\mathrm{~d}, 1 \mathrm{H}, J=15.2 \mathrm{~Hz}, \mathrm{H}_{\alpha}\right), 7.577$ (dd, $1 \mathrm{H}, J=8.8$ and $6.4 \mathrm{~Hz}, \mathrm{Ar}-\mathrm{H}$ ), 7.989 (brs, 2H, Ar-H), 8.071 (d, $\left.1 \mathrm{H} ; J=15.6 \mathrm{~Hz}, \mathrm{H}_{\beta}\right), 8.145(\mathrm{dd}, 1 \mathrm{H}, J=7.2$ and 0.8 Hz, Ar-H), 8.168 (s, 1H, Ar-H), 8.950 (brs, 2H, Ar-H); ${ }^{13} \mathrm{C}$ NMR (100 MHz, DMSO-d 6 ): $\delta 33.1 ; 110.9 ; 111.8$; $114.6 ; 120.6 ; 121.7(3 \mathrm{C}) ; 122.9 ; 125.5 ; 137.7 ; 138.1$; 140.1; 144.6; 150.6(2C); 188.3; ESIMS (Bruker FTMS 4.7T BioAPEX II, $\left.\mathrm{CHCl}_{3} / \mathrm{ACN}\right) \mathrm{m} / z=263.1176$ $(\mathrm{M}+\mathrm{H})^{+}$, calculated for $\mathrm{C}_{17} \mathrm{H}_{15} \mathrm{~N}_{2} \mathrm{O}^{+}: 263.11$.

E-3-(1-Ethylindol-3-yl)-1-(pyridin-4-yl)prop-2-en-1one (3)

Yield $79.73 \%$, bright orange powder, $\mathrm{mp} 128-130^{\circ} \mathrm{C}$; IR $\left(\mathrm{KBr}, \mathrm{cm}^{-1}\right)$ : $v_{\max } 1650(\mathrm{C}=\mathrm{O}), 1594(\mathrm{C}=\mathrm{N}), 1565$ $(\mathrm{C}=\mathrm{C}), 1406 ;{ }^{1} \mathrm{H}$ NMR (400 MHz, DMSO-d 6 ): $\delta 1.43$ (t, $\left.3 \mathrm{H}, \mathrm{N}-\mathrm{CH}_{2}-\mathrm{CH}_{3}\right) ; 4.28$ (m, $\left.2 \mathrm{H}, \mathrm{N}-\mathrm{CH}_{2}-\mathrm{CH}_{3}\right) ; 7.28$ (m, 1H, Ar-H); 7.31 (m, 1H, Ar-H); 7.58 (d, 1H, J= $\left.15.2 \mathrm{~Hz}, \mathrm{H}_{\alpha}\right)$; 7.63 (d, 1H, $J=1.2$ and $\left.6.8 \mathrm{~Hz}, \mathrm{Ar}-\mathrm{H}\right)$; $7.97(\mathrm{~d}, 2 \mathrm{H}, J=6.0 \mathrm{~Hz}, \mathrm{Ar}-\mathrm{H}) ; 8.08$ (d, 1H, $J=15.2$ $\left.\mathrm{Hz}, \mathrm{H}_{\beta}\right) ; 8.13(\mathrm{~d}, 1 \mathrm{H}, J=1.2$ and $6.8 \mathrm{~Hz}, \mathrm{Ar}-\mathrm{H})$; 8.26 (s, 1H, s, Ar-H); 8.83 (d, 2H, J=6.4 Hz, Ar-H); ${ }^{13} \mathrm{C}$ NMR (100 MHz, DMSO-d 6 ): $\delta 15.0 ; 40.9 ; 110.9$; $112.0 ; 114.7 ; 120.7 ; 121.4 ; 121.6 ; 122.9 ; 125.7 ; 135.9$; 137.1; 140.1; 144.7; 150.6; 188.3; ESIMS (Bruker FTMS 4.7T BioAPEX II, $\mathrm{CHCl}_{3} / \mathrm{ACN}$ ) $m / z=277.1332$ $(\mathrm{M}+\mathrm{H})^{+}$, calculated for $\mathrm{C}_{18} \mathrm{H}_{17} \mathrm{~N}_{2} \mathrm{O}^{+}:$277.13.

E-3-(1-Allylindol-3-yl)-1-(pyridin-4-yl)prop-2-en-1one (4)

Yield $91.80 \%$, bright orange powder, $\mathrm{mp} 103-104^{\circ} \mathrm{C}$; IR $\left(\mathrm{KBr}, \mathrm{cm}^{-1}\right)$ : $v_{\max } 1650(\mathrm{C}=\mathrm{O}), 1595(\mathrm{C}=\mathrm{N}), 1566$ $(\mathrm{C}=\mathrm{C}), 1548 ;{ }^{1} \mathrm{H}$ NMR (400 MHz, DMSO-d 6 ): $\delta 4.91$ $\left(\mathrm{d}, 2 \mathrm{H}, J=5.6 \mathrm{~Hz}, \mathrm{~N}-\mathrm{CH}_{2}-\mathrm{CH}=\mathrm{CH}_{2}\right) ; 5.11(\mathrm{dd}, 1 \mathrm{H}$, $J=16.8$ and $\left.1.2 \mathrm{~Hz}, \mathrm{~N}-\mathrm{CH}_{2}-\mathrm{CH}=\mathrm{CH}_{2}\right) ; 5.22(\mathrm{dd}$, $1 \mathrm{H}, J=10.4$ and $\left.1.2 \mathrm{~Hz}, \mathrm{~N}-\mathrm{CH}_{2}-\mathrm{CH}=\mathrm{CH}_{2}\right) ; 6.06$ (m, 1H, N-CH $\left.-\mathrm{CH}=\mathrm{CH}_{2}\right) ; 7.28(\mathrm{~m}, 1 \mathrm{H}, \mathrm{Ar}-\mathrm{H}) ; 7.32$ $(\mathrm{m}, 1 \mathrm{H}, \mathrm{Ar}-\mathrm{H}) ; 7.57(\mathrm{dd}, 1 \mathrm{H}, J=1.2$ and $6.8 \mathrm{~Hz}$, Ar-H); 7.60 (d, 1H, $\left.J=15.6 \mathrm{~Hz}, \mathrm{H}_{\alpha}\right) ; 7.97$ (d, 2H, $J=$ $6.0 \mathrm{~Hz}, \mathrm{Ar}-\mathrm{H}) ; 8.08$ (d, 1H, J=15.6 Hz, $\left.\mathrm{H}_{\beta}\right) ; 8.15$ (d, $1 \mathrm{H}, J=1.2$ and $6.8 \mathrm{~Hz}, \mathrm{Ar}-\mathrm{H}) ; 8.20$ (s, 1H, Ar-H); 8.83 (d, 2H, $J=6.4 \mathrm{~Hz}$, Ar-H); ${ }^{13} \mathrm{C}$ NMR $(100 \mathrm{MHz}$, DMSO-d 6 ): $\delta 48.5 ; 111.2 ; 112.2 ; 115.1 ; 117.6 ; 120.7$; $121.4 ; 121.7 ; 123.0 ; 125.7 ; 133.4 ; 136.5 ; 137.4 ; 140.0$; 144.6; 150.6; 188.4; ESIMS (Bruker FTMS 4.7T BioAPEX II, $\left.\mathrm{CHCl}_{3} / \mathrm{ACN}\right) \mathrm{m} / z=289.1329(\mathrm{M}+\mathrm{H})^{+}$, calculated for $\mathrm{C}_{19} \mathrm{H}_{17} \mathrm{~N}_{2} \mathrm{O}^{+}: 289.13$.

E-3-(1-Benzylindol-3-yl)-1-(pyridin-4-yl)prop-2-en-1one (5)

Yield $78.00 \%$, yellow powder, mp $178-180^{\circ} \mathrm{C}$; IR $\left(\mathrm{KBr}, \mathrm{cm}^{-1}\right)$ : $v_{\max } 1714(\mathrm{C}=\mathrm{O}), 1595(\mathrm{C}=\mathrm{N}), 1565$ $(\mathrm{C}=\mathrm{C}), 1406 ;{ }^{1} \mathrm{H}$ NMR (400 MHz, DMSO-d 6 ): $\delta$ 5.518 (s, 2H, Ar- $\left.\mathrm{CH}_{2-}\right)$, 7.269 - 7.302 (m, 5H, Ar-H), 7,326 (m, 1H, Ar-H), 7,344 (m, 1H, Ar-H), 7.600 (m, $1 \mathrm{H}, \mathrm{Ar}-\mathrm{H}), 7.609$ (d, 1H, $\left.J=15.2 \mathrm{~Hz}, \mathrm{H}_{\alpha}\right), 7.981$ (d, $2 \mathrm{H}, J=5.6 \mathrm{~Hz}, \mathrm{Ar}-\mathrm{H}), 8.091\left(\mathrm{~d}, 1 \mathrm{H} ; J=15.6 \mathrm{~Hz}, \mathrm{H}_{\beta}\right)$, 8.115 (m, 1H, Ar-H), 8.373 (s, 1H, Ar-H), 8.830 (brs, $2 \mathrm{H}, \mathrm{Ar}-\mathrm{H}) ;{ }^{13} \mathrm{C}$ NMR (100 MHz, DMSO-d $\left.6, \mathrm{Me}_{4} \mathrm{Si}\right)$ : $\delta$ 49.6; 111.4; 112.4; 115.3; 120.7; 121.5; 121.7; 123.1;
125.8; 127.2; 127.7; 128.7; 136.8; 137.0; 137.4; 139.9; 144.6; 150.6; 188.4; ESIMS (Bruker FTMS 4.7T BioAPEX II, $\left.\mathrm{CHCl}_{3} / \mathrm{ACN}\right) \mathrm{m} / z=339.1486(\mathrm{M}+\mathrm{H})^{+}$, calculated for $\mathrm{C}_{23} \mathrm{H}_{19} \mathrm{~N}_{2} \mathrm{O}^{+}: 339.4$.

E-3-(1H-Indol-3-yl)-1-(pyridin-3-yl)prop-2-en-1-one (6)

Yield $72.80 \%$, bright orange powder, mp $197-198^{\circ} \mathrm{C}$; IR $\left(\mathrm{KBr}, \mathrm{cm}^{-1}\right): v_{\max } 3088(\mathrm{NH}), 1650(\mathrm{C}=\mathrm{O}), 1585$ $(\mathrm{C}=\mathrm{N}), 1560(\mathrm{C}=\mathrm{C}) ;{ }^{1} \mathrm{H}$ NMR (400 MHz, DMSO-d 6 ): $\delta 7.239(\mathrm{~m}, 1 \mathrm{H}, \mathrm{Ar}-\mathrm{H}), 7.269(\mathrm{~m}, 1 \mathrm{H}, \mathrm{Ar}-\mathrm{H}), 7.507$ (dd, $1 \mathrm{H}, J=6$ and $2.4 \mathrm{~Hz}, \mathrm{Ar}-\mathrm{H}), 7.599(\mathrm{dd}, 1 \mathrm{H}, J=$ 8.0 and $7.6 \mathrm{~Hz}, \mathrm{Ar}-\mathrm{H}), 7.657(\mathrm{~d}, 1 \mathrm{H}, J=15.6 \mathrm{~Hz}$, $\left.\mathrm{H}_{\alpha}\right), 8.113\left(\mathrm{~d}, 1 \mathrm{H}, J=15.6 \mathrm{~Hz}, \mathrm{H}_{\beta}\right), 8.151(\mathrm{dd}, 1 \mathrm{H}$, $J=6.8$ and $2.4 \mathrm{~Hz}, \mathrm{Ar}-\mathrm{H}), 8.175(\mathrm{~s}, 1 \mathrm{H}, \mathrm{Ar}-\mathrm{H})$, $8.459(\mathrm{~d}, 1 \mathrm{H}, J=7.6 \mathrm{~Hz}, \mathrm{Ar}-\mathrm{H}), 8.805$ (d, $1 \mathrm{H}, J=$ $4.8 \mathrm{~Hz}, \mathrm{Ar}-\mathrm{H}), 9.295$ (d, 1H, J=2 Hz, Ar-H), 11.995 (s, 1H, NH); ${ }^{13} \mathrm{C}$ NMR (100 MHz, DMSO-d 6$): \delta 112.4$; $112.8 ; 115.1 ; 120.5 ; 121.2 ; 122.8 ; 123.8 ; 125.1 ; 133.6$; 133.8; 135.6; 137.5; 139.8; 149.2; 152.6; 187.8; ESIMS (Bruker FTMS 4.7T BioAPEX II, $\mathrm{CHCl}_{3} / \mathrm{ACN}$ ) $\mathrm{m} / \mathrm{z}=$ 249.1020 $(\mathrm{M}+\mathrm{H})^{+}$, calculated for $\mathrm{C}_{16} \mathrm{H}_{13} \mathrm{~N}_{2} \mathrm{O}^{+}: 249.09$. E-3-(1-Methylindol-3-yl)-1-(pyridin-3-yl)prop-2-en-1one (7)

Yield $68.84 \%$, bright orange powder, $\mathrm{mp} 156-157^{\circ} \mathrm{C}$; IR $\left(\mathrm{KBr}, \mathrm{cm}^{-1}\right)$ : $v_{\max } 1648(\mathrm{C}=\mathrm{O}), 1585(\mathrm{C}=\mathrm{N}), 1556$ $(\mathrm{C}=\mathrm{C}) ;{ }^{1} \mathrm{H}$ NMR (400 MHz, DMSO-d $): \delta 3.87$ (s, 3H, $\left.\mathrm{NCH}_{3}\right) ; 7.32$ (m, 1H, Ar-H); 7.34 (m, 1H, Ar-H); 7.50 $(\mathrm{dd}, 1 \mathrm{H}, J=6.0$ and $6.4 \mathrm{~Hz}, \mathrm{Ar}-\mathrm{H}) ; 7.59(\mathrm{dd}, 1 \mathrm{H}, J=$ 1.2 and $6.8 \mathrm{~Hz}, \mathrm{Ar}-\mathrm{H}) ; 7.64\left(\mathrm{~d}, 1 \mathrm{H}, J=15.2 \mathrm{~Hz}, \mathrm{H}_{\alpha}\right)$; 8.07 (d, $\left.1 \mathrm{H}, J=15.2 \mathrm{~Hz}, \mathrm{H}_{\beta}\right) ; 8.16$ (s, $\left.1 \mathrm{H}, \mathrm{Ar}-\mathrm{H}\right) ; 8.18$ (dd, $1 \mathrm{H}, J=1.2$ and $6.8 \mathrm{~Hz}, \mathrm{Ar}-\mathrm{H}) ; 8.46(\mathrm{dd}, 1 \mathrm{H}, J=$ 1.2 and $6.4 \mathrm{~Hz}, \mathrm{Ar}-\mathrm{H})$ ); 8.81 (dd, $1 \mathrm{H}, J=1.6$ and 6.0 $\mathrm{Hz}, \mathrm{Ar}-\mathrm{H}) ; 9.29$ (d, 1H, $J=2.0 \mathrm{~Hz}, \mathrm{Ar}-\mathrm{H}) ;{ }^{13} \mathrm{C} \mathrm{NMR}$ $\left(100 \mathrm{MHz}, \mathrm{DMSO}-\mathrm{d}_{6}\right): \delta 33.1 ; 110.8 ; 111.8 ; 115.0$; 120.7 ; $121.5 ; 122.8 ; 123.8 ; 125.5 ; 133.6 ; 135.6$; 137.2; 138.0; 138.1; 149.2; 152.6; 187.7; ESIMS (Bruker FTMS 4.7T BioAPEX II, $\mathrm{CHCl}_{3} / \mathrm{ACN}$ ) $m / z=263.1176$ $(\mathrm{M}+\mathrm{H})^{+}$, calculated for $\mathrm{C}_{17} \mathrm{H}_{15} \mathrm{~N}_{2} \mathrm{O}^{+}$: 263.12 . Cytotoxicity study

The resazurin reduction assay was performed to assess the cytotoxicity of compounds 1-7 and doxorubicin was used as the control drug towards various sensitive and drug-resistant cancer cell lines, including the CCRF-CEM and CEM/ADR5000 leukaemia, MDAMB231 breast cancer cells and its resistant subline MDA-MB231/BCRP, HCT116p53 $3^{+/+}$colon cancer cells and its resistant subline HCT116p53\%-, U87MG glioblastoma cells and its resistant subline U87MG. $\triangle E G F R$ and HepG2 hepatocarcinoma cells and normal AML12 hepatocytes. The assay is based on the reduction of the indicator dye, resazurin, to the highly fluorescent resorufin by viable cells. Non-viable cells rapidly lose their metabolic capacity to reduce resazurin and, thus, do not produce fluorescent signals anymore. Briefly, adherent cells were detached by treatment with $0.25 \%$ trypsin/EDTA (Invitrogen, Darmstadt Germany) and an aliquot of $1 \times 10^{4}$ cells was placed in each well of a 96-well cell culture plate (Thermo Scientific, 
Langenselbold, Germany) in a total volume of 200 $\mu \mathrm{L}$. Cells were allowed to attach overnight and then were treated with different concentrations of compounds. For suspension cells, aliquots of $2 \times 10^{4}$ cells per well were seeded in 96-well-plates in a total volume of $100 \mu \mathrm{L}$. The studied compound was immediately added in varying concentrations in an additional $100 \mu \mathrm{L}$ of culture medium to obtain a total volume of $200 \mu \mathrm{L}$ per well. After $72 \mathrm{~h}$, resazurin (Sigma-Aldrich, Schnelldorf, Germany) $(20 \mu \mathrm{L}, 0.01 \% \mathrm{w} / \mathrm{v})$ in distilled $\mathrm{H}_{2} \mathrm{O}$ was added to each well and the plates were incubated at $37^{\circ} \mathrm{C}$ for $4 \mathrm{~h}$. Fluorescence was measured on an Infinite M 2000 ProTM plate reader (Tecan, Crailsheim, Germany) using an excitation wavelength of $544 \mathrm{~nm}$ and an emission wavelength of $590 \mathrm{~nm}$. Each assay was done at least twice with six replicates each. The viability was evaluated based on a comparison with untreated cells. $\mathrm{IC}_{50}$ values represent the compound concentrations required to inhibit $50 \%$ of cell proliferation and were calculated from a calibration curve by linear regression using Microsoft Excel.

\section{Results and Discussion}

\section{Chemistry}

The synthetic route using Claisen-Schmidt condensation of these target compounds 1-7 is outlined in Figure 1. Indol-3-carboxaldehydes 3a-g (1 equiv.) and appropriate acetylpyridine (1.5 equiv.) in anhydrous methanol were refluxed in the presence of piperidine (1.5 equiv.) affording the corresponding 3-indolyl-1-pyridyl-2propenones 1-7. Compounds 2 and 3 were purified by column chromatography while compounds 1, 4-7 were precipitated directly, filtered and washed with ice-cold methanol and air dried.

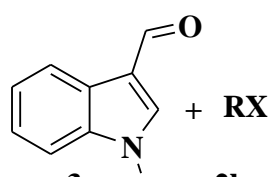

3a $\quad$ H $2 b-e$<smiles>[R]n1cc(C=O)c2ccccc21</smiles><smiles>CC(=O)P</smiles>

II.<smiles>[R17]C(=O)/C=C/c1cn([R])c2ccccc12</smiles>

\begin{tabular}{|c|c|c|}
\hline Compound & $\mathbf{R}$ & Py \\
\hline 1 & $\mathbf{H}$ & \\
\hline $2 \mathrm{~b} / 3 \mathrm{~b} / 2$ & $\mathrm{CH}_{3}$ & \\
\hline $2 c / 3 c / 3$ & $\mathrm{CH}_{2} \mathrm{CH}_{3}$ & \\
\hline $2 d / 3 d / 4$ & $\mathrm{CH}_{2} \mathrm{CH}=\mathrm{CH}_{2}$ & \\
\hline $2 \mathrm{e} / 3 \mathrm{e} / 5$ & $\mathrm{CH}_{2}-\mathrm{C}_{6} \mathrm{H}_{5}$ & \\
\hline $3 f / 6$ & $\mathbf{H}$ & \\
\hline $3 g / 7$ & $\mathrm{CH}_{3}$ & \\
\hline
\end{tabular}

Figure 1.

Synthesis of 3-indolyl-1-pyridyl-2-propenones 1-7

Reaction conditions: I. anhydrous $\mathrm{K}_{2} \mathrm{CO}_{3}, \mathrm{~N}, \mathrm{~N}$-dimethylformamide, r.t. $1 \mathrm{~h}$ and then reflux 16 - $24 \mathrm{~h}$;

II. pyperidine, dry methanol, reflux $20-26 \mathrm{~h}$

3-Indolyl-1-pyridyl-2-propenones 1-7 were obtained by the above mentioned procedure with $68.8-91.8 \%$ yields. Their structures were confirmed by melting points, IR, ${ }^{1} \mathrm{H}$ NMR, ${ }^{13} \mathrm{C}$ NMR and HRMS analysis. In the IR spectra of compounds 1-7, the stretching vibrations of the carbonyl groups appeared at 1714 $1644 \mathrm{~cm}^{-1}$. The characteristic bands for the $\mathrm{C}=\mathrm{C}$ bond of the propenone chain appeared at $1566-1556 \mathrm{~cm}^{-1}$, while the stretching vibrations of the $\mathrm{C}=\mathrm{N}$ bond were present at $1604-1563 \mathrm{~cm}^{-1}$. The ${ }^{1} \mathrm{H}$ NMR spectra of the N-unsubstituted 3-indolyl-1-pyridyl-2-propenones showed characteristic signals of the $\mathrm{NH}$ proton at approximately $12 \mathrm{ppm}$. All synthesized compounds present characteristic signals of the two vinylic protons $\mathrm{H}_{\alpha}$ and $\mathrm{H}_{\beta}$ of the propenone chain as two doublets at $\delta_{\mathrm{H}} 7.57-7.65\left(\mathrm{H}_{\alpha}\right)$ and $\delta_{\mathrm{H}} 8.07-8.11\left(\mathrm{H}_{\beta}\right)$. The high coupling constant $(J=15.2-15.6 \mathrm{~Hz})$ of the two doublets corresponding to protons $\mathrm{H}_{\alpha}$ and $\mathrm{H}_{\beta}$ of the propenone chain indicates that the 3-indolyl-1-pyridylpropenones were obtained with E configuration [29].
Aromatic protons of the pyridine and indole rings were found between 7.24 to $9.29 \mathrm{ppm}$, where the $\mathrm{H}-2$ of the indole ring is also found as a singlet at $8.15-8.37 \mathrm{ppm}$. [22]. In case of the N-substituted indolyl propenones with aliphatic residues (N-methyl, $\mathrm{N}$-ethyl, $\mathrm{N}$-allyl), the corresponding signals of the aliphatic protons were present in the aliphatic area. In the ${ }^{13} \mathrm{C}$ NMR spectra of the 3-indolyl-1-pyridyl-2propenones, characteristic signals at 187.7 - 188.4 ppm were indicative of the conjugated carbonyl group [29] while $\mathrm{C}_{\alpha}$ and $\mathrm{C}_{\beta}$ were found around $122.8-123.0 \mathrm{ppm}$ and 138.1 - $144.7 \mathrm{ppm}$, respectively. Other signals corresponding to the unsaturated/aromatic $\mathrm{sp}^{2}$ carbons located in the vinyl group and benzene ring respectively were located around $110.8-144.7 \mathrm{ppm}$.

In the high resolution ESI MS spectra, the molecular ions $[\mathrm{M}+\mathrm{H}]^{+}$are present for all the synthesized compounds and the obtained experimental values are in accordance with the corresponding theoretically calculated molecular weights. Based on all these data, 
the structures of 1-7 were univocally determined as shown in Figure 1. The synthesized compounds 1 [29], and $6[18,21]$ were previously described.

Cytotoxicity study

The cytotoxicity of compounds 1-7 and doxorubicin was first determined in a panel of nine human cancer cell lines including both sensitive and drug-resistant phenotypes, as well as in normal AML12 hepatocytes (Table I). Compounds 3, 4 and 7 displayed $\mathrm{IC}_{50}$ values below $100 \mu \mathrm{M}$ in all tested cancer cell lines, meanwhile other compounds displayed selective activities.

In CEM/ADR5000 leukaemia cells, significant activity with $\mathrm{IC}_{50}$ values below $10 \mu \mathrm{M}[3,10]$ were obtained with compounds $3(9.62 \mu \mathrm{M})$ and $7(9.90 \mu \mathrm{M})$. It is worth noting that CEM/ADR5000 cells were highly resistant to doxorubicin contrary to the test compounds 3, 4 and 7. Hypersensitivity (degree of resistance or D.R. below 0.90) [16] CEM/ADR5000 compared to it sensitive parental cell line CCRF-CEM was noted with compounds 3,4 and 7, suggesting that they might have inhibitory effect on P-glycoprotein's expression [16]. Besides, hypersensitivity was obtained with $\mathbf{3}$ towards resistant MDA-MB231/BCRP cells [7], HCT$116\left(p 53^{-/}\right)$and U87MG. $\triangle E G R F$ cells as well as with 4 and 7 in MDA-MB231/BCRP cells compared to their respective sensitive counterparts MDA-MB231 cells, HCT116 $\left(p 53^{+/+}\right)$cells and U87MG cells. It is also important to note that the selectivity indexes of compounds 3, 4 and $\mathbf{7}$ for the normal AML12 hepatocytes versus hepatocarcinoma HepG2 cells are above 1, suggesting their good selectivity to liver cancer cells. The overall data highlights the good activity of compounds 3, 4 and 7. These compounds are potential cytotoxic agents that could be used or explored more to develop novel drugs to fight drug sensitive and resistant cancers. A lipophilic molecule with positive charge promotes mitochondrial membrane adhesion that eventually leads to apoptosis when incubated at high micromolar concentration [23]. In case of the 3-indolyl-1-pyridyl2-propenones, the nitrogen atoms can be protonated under the influence of the mitochondrial membrane potential which is generated by proton pumps, and the compounds become molecules with positive charge that can adhere to the mitochondrial membrane. Moreover, in case of compounds $\mathbf{3}, \mathbf{4}$ and $\mathbf{7}$ an enhancement of the cytotoxicity and selectivity was observed, which could be explained by the increase in the lipophilic character of these molecules due to the substitution of the hydrogen atom from the indole ring by the ethyl, allyl and methyl groups, respectively.

Table I

Cytotoxicity of the studied compounds (1-7) and doxorubicin towards drug sensitive and resistant cancer cells as determined by resazurin assay

\begin{tabular}{|c|c|c|c|c|c|c|c|c|}
\hline \multirow[t]{2}{*}{ Cell lines } & \multicolumn{7}{|c|}{$\mathrm{IC}_{50}$ value in $\mu \mathrm{M}$ and degree of resistance } & \multirow[b]{2}{*}{ Doxorubicin } \\
\hline & $\mathbf{1}$ & 2 & 3 & 4 & 5 & 6 & 7 & \\
\hline CCRF-CEM & $>100$ & $>100$ & $35.34 \pm 3.61$ & $44.47 \pm 3.23$ & $84.10 \pm 6.39$ & $>100$ & $28.66 \pm 1.05$ & $0.02 \pm 0.00$ \\
\hline $\begin{array}{l}\text { CEM/ADR5000 } \\
\text { (D.R.)* }\end{array}$ & $>100$ & $>100$ & $\begin{array}{c}\mathbf{9 . 6 2} \pm \mathbf{0 . 7 7} \\
(0.27) \\
\end{array}$ & $\begin{array}{c}13.03 \pm 2.01 \\
(0.29)\end{array}$ & $>100$ & $>100$ & $\begin{array}{c}\mathbf{9 . 9 0} \pm \mathbf{1 . 0 0} \\
(0.35)\end{array}$ & $\begin{array}{c}122.96 \pm 10.94 \\
(6,683.00) \\
\end{array}$ \\
\hline MDA-MB231 & $>100$ & $>100$ & $48.21 \pm 3.56$ & $22.26 \pm 1.81$ & $>100$ & $>100$ & $63.36 \pm 4.91$ & $0.13 \pm 0.01$ \\
\hline $\begin{array}{l}\text { MDA-MB231/BCRP } \\
\text { (D.R.)* }\end{array}$ & $>100$ & $>100$ & $\begin{array}{c}46.26 \pm 3.29 \\
(0.96)\end{array}$ & $\begin{array}{c}16.44 \pm 1.11 \\
(0.74)\end{array}$ & $>100$ & $>100$ & $\begin{array}{c}49.66 \pm 2.97 \\
(0.78)\end{array}$ & $\begin{array}{l}\mathbf{0 . 7 9} \pm \mathbf{0 . 0 8} \\
\quad(6.14)\end{array}$ \\
\hline HCT116 $\left(p 53^{+/+}\right)$ & $>100$ & $>100$ & $24.54 \pm 2.78$ & $34.92 \pm 3.58$ & $>100$ & $>100$ & $33.14 \pm 1.76$ & $0.48 \pm 0.06$ \\
\hline $\begin{array}{l}\text { HCT116 }\left(\mathrm{p53}^{-/-}\right) \\
\text {(D.R.)* }\end{array}$ & $>100$ & $>100$ & $\begin{array}{c}16.08 \pm 2.01 \\
(0.66)\end{array}$ & $\begin{array}{c}35.98 \pm 2.10 \\
(1.03)\end{array}$ & $>100$ & $>100$ & $\begin{array}{c}24.67 \pm 1.09 \\
(0.74)\end{array}$ & $\begin{array}{c}\mathbf{1 . 7 8} \pm \mathbf{0 . 0 8} \\
\quad(3.73)\end{array}$ \\
\hline U87MG & $>100$ & $>100$ & $19.58 \pm 0.88$ & $24.98 \pm 2.18$ & $>100$ & $>100$ & $23.30 \pm 1.86$ & $0.26 \pm 0.03$ \\
\hline $\begin{array}{l}\text { U87MG. } \triangle E G F R \\
\text { (D.R.)* }\end{array}$ & $>100$ & $>100$ & $\begin{array}{l}18.01 \pm 0.84 \\
(0.92)\end{array}$ & $\begin{array}{c}30.72 \pm 2.06 \\
(1.23)\end{array}$ & $>100$ & $>100$ & $\begin{array}{c}42.24 \pm 3.19 \\
(1.81)\end{array}$ & $\begin{array}{l}\mathbf{0 . 9 8} \pm \mathbf{0 . 0 7} \\
\quad(3.79)\end{array}$ \\
\hline HepG2 & $>100$ & $>100$ & $42.87 \pm 4.42$ & $29.03 \pm 2.87$ & $>100$ & $>100$ & $40.57 \pm 3.12$ & $4.56 \pm 0.48$ \\
\hline $\operatorname{AML12}($ S.I.)** & $>100$ & $>100$ & $\begin{array}{c}66.23 \pm 5.67 \\
(1.55)\end{array}$ & $\begin{array}{c}48.43 \pm 2.80 \\
(1.67)\end{array}$ & $>100$ & $>100$ & $\begin{array}{l}>100 \\
(>2.46)\end{array}$ & $\begin{array}{c}52.90 \pm 4.09 \\
(11.59)\end{array}$ \\
\hline
\end{tabular}

(*): The degree of resistance (D.R.) was determined as the ratio of $\mathrm{IC}_{50}$ value in the resistant divided by the $\mathrm{IC}_{50}$ in the sensitive cell line; CEM/ADR5000, MDA-MB-231-BCRP, HCT116 (p53 $\left.{ }^{-/}\right)$and U87MG. $\triangle E G F R$ were used as the corresponding resistant counterpart for CCRF-CEM, MDA-MB-231-pcDNA, HCT116 $\left(p 53^{+/+}\right)$, U87MG respectively; (**): The selectivity index (S.I.) was determined as the ratio of $\mathrm{IC}_{50}$ value in the normal AML12 hepatocytes divided by the $\mathrm{IC}_{50}$ in $\mathrm{HepG} 2$ hepatocarcinoma cells; $\mathrm{IC}_{50}$ value in bold: Significant activity [3]

\section{Conclusions}

In summary, seven indole-based chalcones analogues with various substituents (1-7) were prepared using Claisen-Schmidt condensation. The synthesized compounds were tested against several cancer cell lines including both sensitive and their resistant counterparts. The overall data highlights the good activity of compounds
3, 4 and 7. These compounds are potential cytotoxic agents that could be used or explored more to develop novel drugs to fight drug sensitive and resistant cancers.

\section{Acknowledgement}

JK and VZ are grateful to AUF - "Eugen Ionescu" Program (N/Ref: CE/DG/79-20/2016) for the financial 
support. ATM is thankful to "Alexander von Humboldt" Foundation for an 18 months fellowship in Prof. Dr. Thomas Efferth's laboratory in Mainz, Germany, through the "Georg Foster Research Fellowship for Experienced Researcher" program. VK is very grateful to the Alexander von Humboldt Foundation for the funding through the Linkage program (2015 - 2018); Authors are indebted to Dr. Frederic Nana of the University of Lorraine and Prof. Christian G. Bochet of Freiburg University for their great assistance by carrying out respectively the NMR and IR spectra data.

\section{Conflict of interest}

The authors declare no conflict of interest.

\section{References}

1. Awoussong PK, Zaharia V, Ngameni B, Kuete V, Ntede HN, Fokunang CN, Abegaz BM, Ngadjui BT, Heterocycles 26: Synthesis, characterisation and anticancer activity of some thiazolic chalcones. Med Chem Res., 2015; 24(1): 131-141.

2. Boeck P, Falcao CAB, Leal PC, Yunes RA, Filho CV, Torres SEC, Bergmann BR, Synthesis of chalcone analogues with increased antileishmanial activity. Bioorg Med Chem., 2006; 14(5): 1538-1545.

3. Brahimi G, Kona FR, Fiasella A, Buac D, Soukupova J, Brancale A, Burger AM, Westwell AD, Exploring the structural requirements for inhibition of the ubiquitin E3 ligase breast cancer associated protein 2 (BCA2) as a treatment for breast cancer. J Med Chem., 2010; 53(7): 2757-2765.

4. Chetana BP, Mahajan SK and Suvarna AK, Chalcone: A Versatile Molecule. J Pharm Sci \& Res., 2009; 1(3): 11-22.

5. Coman FM, Mbaveng A, Denisa L, Laszlo CB, Vlase L, Imre S, Kuete V, Efferth T, Zaharia V, Heterocycles 44. Synthesis, characterization and anticancer activity of new thiazole ortho-hydroxychalcones. Med Chem Res., 2018; 27: 1396-1407.

6. Coman FM, Mbaveng AT, Marc G, Leonte D, Brém B, Vlase L, Imre S, Kuete V, Zaharia V, Heterocycles 47. Synthesis, characterization and biological evaluation of some new thiazole aurones as antiproliferative agents. Farmacia, 2020; 68(3): 492-506.

7. Doyle LA, Yang W, Abruzzo LV, Krogmann T, Gao Y, Rishi AK, Ross DD, A multidrug resistance transporter from human MCF-7 breast cancer cells. Proc Nat Acad Sci USA., 1998; 95(26): 15665-15670.

8. Gavrilovici C, Luca A, Antoniu SA, Gallaby K, Ștefănescu R, Stârcea M, Miron I, Bild V, How nephrotoxic is cancer therapy in children?. Farmacia, 2018; 66(2): 197-208.

9. Ivănescu B, Tuchiluș C, Corciovă A, Lungu C, Mihai CT, Gheldiu AM, Vlase L, Antioxidant, antimicrobial and cytotoxic activity Tanacetum vulgare, Tanacetum corymbosum and Tanacetum macrophyllum extracts. Farmacia, 2018; 66(2): 282-288.

10. Kuete V, Efferth T, African flora has the potential to fight multidrug resistance of cancer. Bio Med Res Int., 2015; 1-24.

11. Kumar D, Kumar NM, Akamatsu K, Kusaka E, Harada $\mathrm{H}$, Ito $\mathrm{T}$, Synthesis and biological evaluation of indolyl chalcones as antitumor agents. Bioorg Med Chem Lett., 2010; 20(13): 3916-3919.

12. Lahtchev KL, Batovska DI, Parushev SP, Ubiyvovk VM, Sibirny AA, Antifungal activity of chalcones: a mechanistic study using various yeast strains. Eur $J$ Med Chem., 2008; 43(10): 2220-2228.

13. Li R, Kenyon GL, Cohen FE, Chen X, Gong B, Dominguez JN, Davidson E, Kurzban G, Miller RE, Nuzum EO, Rosenthal PJ, Mc Kerrow JH, In vitro antimalarial activity of chalcones and their derivatives. J Med Chem., 1995; 38(26): 5031-5037.

14. Lin Y, Zhou Y, Flavin MT, Zhou LM, Nie W, Chen FC, Chalcones and flavonoids as anti-tuberculosis agents. Bioorg Med Chem Lett., 2002; 10(8): 2795-2802.

15. Mager S, Zaharia V, Horn M, Simiti I, Heterocyclen 69 Mitt.: Das Verhalten einiger ortho-hydroxyheterochalcone under dem einvirkung von hydrazinen. Arch Pharm (Weinheim), 1992; 325: 613-615, (available in German).

16. Mbaveng AT, Kuete V, Efferth T, Potential of Central, Eastern and Western Africa medicinal plants for cancer therapy: spotlight on resistant cells and molecular targets. Front Pharmacol., 2017; 8: 343-374.

17. Nowakowska $\mathrm{Z}, \mathrm{A}$ review of anti-infective and antiinflammatory chalcones. Eur J Med Chem., 2007; 42(2): 125-130.

18. Peerzada MN, Khan P, Ahmad K, Hassan MI, Azam A, Synthesis, characterization and biological evaluation of tertiary sulfonamide derivatives of pyridyl-indole based heteroaryl chalcone as potential carbonic anhydrase IX inhibitors and anticancer agents. Eur J Med Chem., 2018; 155: 13-23.

19. Quintin J, Desrivot J, Thoret S, Menez P, Cresteil T, Lewin G, Synthesis and biological evaluation of a series of tangeretin-derived chalcones. Bioorg Med Chem Lett., 2009; 19(1): 167-169.

20. Rani P, Srivastava VK, Kumar A, Synthesis and antiinflammatory activity of heterocyclic indole derivatives. Eur J Med Chem., 2004; 39(5): 449-452.

21. Robinson MW, Overmeyer JH, Young AM, Erhardt PW, Maltese WA, Synthesis and evaluation of indolebased chalcones as inducers of methuosis, a novel type of nonapoptotic cell death. J Med Chem., 2012; 55(5): 1940-1956.

22. Romagnoli R, Prencipe F, Lopez-Cara LC, Oliva P, Baraldi S, Baraldi PG, Estévez-Sarmiento F, Quintana J, Francisco-Estévez F, Synthesis and biological evaluation of alpha-bromoacryloylamido indolyl pyridyl propenones as potent apoptotic inducers in human leukaemia cells. J Enz Inhib Med Chem., 2018; 33(1): 727-742.

23. Rubio SG, Pastor NM, Garcia C, Almendro-Vedia VG, Ferrer I, Natale P, Paz-Ares L, Lillo MP, LopezMontero I, Enhanced Cytotoxic Activity of Mitochondrial Mechanical Effectors in Human Lung Carcinoma H520 Cells: Pharmaceutical Implications for Cancer Therapy. Front Oncol., 2018; 8: 514-562.

24. Shah A, Khan AM, Qureshi R, Ansari FL, Nazar FM, Shah SS, Redox Behavior of Anticancer Chalcone on a Glassy Carbon Electrode and Evaluation of its Interaction Parameters with DNA. Int J Mol Sci., 2008; 9(8): 1424-1434.

25. Sharma V, Kumar V, Kumar P, Heterocyclic chalcone analogues as potential anticancer agents. Med Chem., 2013; 13(3): 422-432. 
26. Simiti I, Zaharia V, Coman M, Demian H, Mureşan A, Heterocyclen 62. Mitt:: Darstellung und charakterisierung einiger 1,3-Diaryl-5[(2-aryl-5-X)-thiazol-4-yl]pirazoles. Pharmazie, 1998; 43: 82-84, (available in German).

27. Simiti I, Zaharia V, Mager S, Horn M, Köteles-Popa T, Heterocyclen 67 Mitt.: Darstellung und charakterisierung einiger 2-(2-aryl-thiazol-4-yl)-3-hydroxy-chromone. Arch Pharm (Weinheim), 1991; 324: 913-915, (available in German).

28. Thanh-Ha D, Dai-Minh N, Van-Dat T, Thi-Hong-Tuoi D, Minh-Tri L, Thanh-Quan P, Khac-Minh T, ThanhDao T, Synthesis and Selective Cytotoxic Activities on Rhabdomyosarcoma and Noncancerous Cells of Some Heterocyclic Chalcones. Molecules, 2016; 21(3): 329-339.
29. Trabbic JC, George MS, Alexander ME, Du S, Offenbacher MJ, Crissman JE, Overmeyer HJ, Maltese AW, Erhard WP, Synthesis and biological evaluation of isomeric methoxy substitutions on anti-cancer 3indolyl-1-pyridyl-propenones: Effects on potency and mode of activity. Eur J Med Chem., 2016; 122: 79-91.

30. Won SJ, Liu CT, Tsao LT, Weng JR, Ko HH, Wang JP, Lin CN, Synthetic chalcones as potential antiinflammatory and cancer chemopreventive agents. Eur J Med Chem., 2005; 40(1): 103-112.

31. Zaharia V, Imre S, Palibroda N, Heterocycles. Obtaining and Physico-chemical Characterization of Some Thiazolo and Thiazolo[3,2-b][1,2,4]Triazolic Hydroxy-heterochalcones. Rev Chim., 2009; 60(4): 391-397. 